\section{PROCEEDINGS B}

rspb.royalsocietypublishing.org

\section{Research}

Cite this article: Comeau S, Tambutté $\mathrm{E}$, Carpenter RC, Edmunds PJ, Evensen NR, Allemand D, Ferrier-Pagès C, Tambutté S, Venn AA. 2017 Coral calcifying fluid pH is modulated by seawater carbonate chemistry not solely seawater pH. Proc. R. Soc. B 284: 20161669. http://dx.doi.org/10.1098/rspb.2016.1669

Received: 25 July 2016

Accepted: 2 December 2016

\section{Subject Category:}

Global change and conservation

\section{Subject Areas:}

environmental science

\section{Keywords:}

calcification, protons, dissolved inorganic carbon, total alkalinity, ocean acidification

\section{Author for correspondence:}

\section{S. Comeau}

e-mail: steeve.comeau@uwa.edu.au

A. A. Venn

e-mail: avenn@centrescientifique.mc

Electronic supplementary material is available online at https://dx.doi.org/10.6084/m9.figshare.c.3649919.

\section{Coral calcifying fluid $\mathrm{pH}$ is modulated by seawater carbonate chemistry not solely} seawater $\mathrm{pH}$

\author{
S. Comeau ${ }^{1,2}$, E. Tambutté ${ }^{3,4}$, R. C. Carpenter ${ }^{1}$, P. J. Edmunds', \\ N. R. Evensen ${ }^{1,5}$, D. Allemand ${ }^{3,4}$, C. Ferrier-Pagès ${ }^{3,4}$, S. Tambutté3,4 \\ and A. A. Venn 3,4
}

${ }^{1}$ Department of Biology, California State University, 18111 Nordhoff Street, Northridge, CA 91330-8303, USA ${ }^{2}$ School of Earth and Environment and ARC Centre of Excellence for Coral Reef Studies, The University of Western Australia, Crawley, Western Australia 6009, Australia

${ }^{3}$ Marine Biology Department, Centre Scientifique de Monaco, 8 Quai Antoine 1er, MC98000, Monaco ${ }^{4}$ Laboratoire International Associé 647 «BIOSENSIB», Centre Scientifique de Monaco-Centre National de la Recherche Scientifique, 8 Quai Antoine 1er, MC98000, Monaco

${ }^{5}$ Marine Spatial Ecology Lab, ARC Centre of Excellence for Coral Reef Studies and School of Biological Sciences, The University of Queensland, St Lucia, Queensland 4072, Australia

\title{
SC, 0000-0002-6724-5286
}

Reef coral calcification depends on regulation of $\mathrm{pH}$ in the internal calcifying fluid (CF) in which the coral skeleton forms. However, little is known about calcifying fluid $\mathrm{pH}\left(\mathrm{pH}_{\mathrm{CF}}\right)$ regulation, despite its importance in determining the response of corals to ocean acidification. Here, we investigate $\mathrm{pH}_{\mathrm{CF}}$ in the coral Stylophora pistillata in seawater maintained at constant $\mathrm{pH}$ with manipulated carbonate chemistry to alter dissolved inorganic carbon (DIC) concentration, and therefore total alkalinity $\left(\mathrm{A}_{\mathrm{T}}\right)$. We also investigate the intracellular $\mathrm{pH}$ of calcifying cells, photosynthesis, respiration and calcification rates under the same conditions. Our results show that despite constant $\mathrm{pH}$ in the surrounding seawater, $\mathrm{pH}_{\mathrm{CF}}$ is sensitive to shifts in carbonate chemistry associated with changes in $[\mathrm{DIC}]$ and $\left[\mathrm{A}_{\mathrm{T}}\right]$, revealing that seawater $\mathrm{pH}$ is not the sole driver of $\mathrm{pH}_{\mathrm{CF}}$. Notably, when we synthesize our results with published data, we identify linear relationships of $\mathrm{pH}_{\mathrm{CF}}$ with the seawater $[\mathrm{DIC}] /\left[\mathrm{H}^{+}\right]$ratio, $\left[\mathrm{A}_{\mathrm{T}}\right] /\left[\mathrm{H}^{+}\right]$ratio and $\left[\mathrm{CO}_{3}^{2-}\right]$. Our findings contribute new insights into the mechanisms determining the sensitivity of coral calcification to changes in seawater carbonate chemistry, which are needed for predicting effects of environmental change on coral reefs and for robust interpretations of isotopic palaeoenvironmental records in coral skeletons.

\section{Introduction}

The structural basis of one of the world's most biodiverse habitats, coral reef ecosystems, is composed of a $\mathrm{CaCO}_{3}$ framework largely built by the calcification of scleractinian corals. Despite the importance of coral calcification in building and maintaining reef structures, relatively little is understood about calcification at a mechanistic, physiological level [1].

Critical to the calcification mechanism of reef corals is the ability to regulate $\mathrm{pH}$ in the extracellular calcifying fluid (CF) where the skeleton forms [2,3]. The $\mathrm{CF}$ is separated from the surrounding seawater by the overlying coral tissues, and is at the interface between the coral skeleton and the calcifying calicoblastic epithelium (figure 1a). Knowledge of the chemistry of the CF is limited, but it has been shown that corals increase $\mathrm{pH}_{\mathrm{CF}}$ to exceed that of the surrounding seawater $\mathrm{pH}$ in order to increase the aragonite saturation state $\left(\Omega_{\mathrm{arag}}\right)$ of the $\mathrm{CF}$ and promote precipitation of $\mathrm{CaCO}_{3}$ [2,3,10-13].

Previous research has attempted to better characterize both biological and seawater environmental parameters that influence $\mathrm{pH}_{\mathrm{CF}}$ in order to better understand the calcification process. At the cellular level, biological regulation 


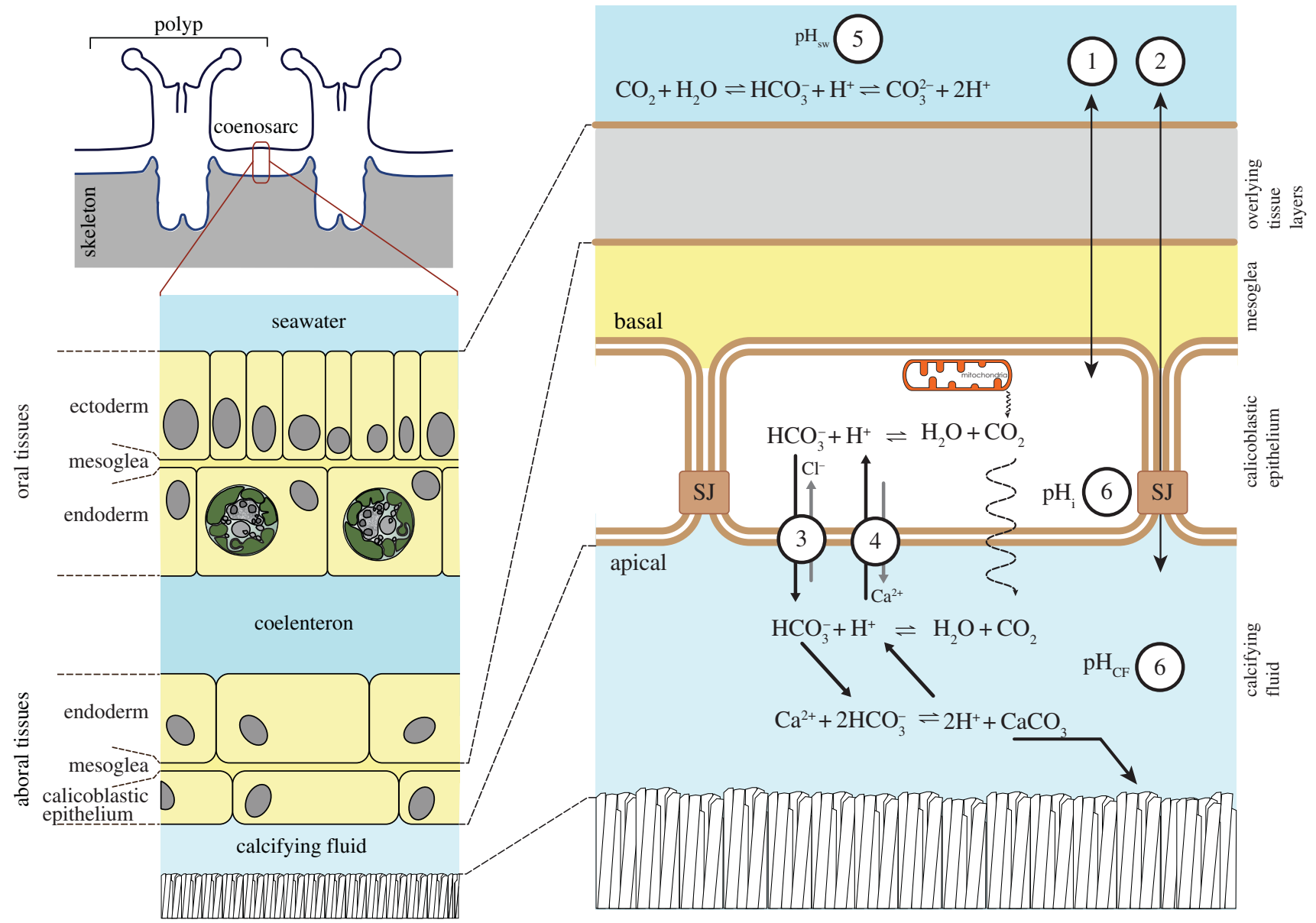

Figure 1. (a) Schematic of cross section through the coral tissues at the coenosarc. (b) Schematic of ion transport processes influencing calcifying fluid (CF) pH in Stylophora pistillata. (1-4) Ion exchange between seawater, the CF and calicoblastic cells occurs via (1) transcellular and (2) paracellular pathways [4-7]. (3 and 4) Transcellular pathways include $\mathrm{HCO}_{3}^{-}$transport by a SLC4y transporter localized to the apical calicoblastic membrane [4] and the removal of protons from the $\mathrm{CF}$ via the $\mathrm{Ca}^{2+}$ ATPase [8]. (5 and 6) Changes in seawater carbonate chemistry associated with shifts in seawater [DIC] and $\mathrm{A}_{\mathrm{T}}$, and also seawater $\mathrm{pH}$, affect $\mathrm{pH}$ in the calicoblastic cells and $\mathrm{pH}_{\mathrm{CF}}$ (this study and [9]). SJ, septate junction.

of $\mathrm{pH}_{\mathrm{CF}}$ is typically attributed to proton transporters situated in the calicoblastic epithelium, particularly $\mathrm{Ca}^{2+}$ ATPases, which have been proposed to remove protons from the $\mathrm{CF}$, thus elevating $\mathrm{pH}$ [8] (figure 1b). Physiological studies and recent molecular work have also described cnidarian $\mathrm{HCO}_{3}^{-}$ transporters in the calicoblastic cell layer that may be involved in transporting dissolved inorganic carbon (DIC) for calcification, thus influencing CF chemistry $[4,14]$ (figure $1 b$ ). At the organism scale, there is evidence that photosynthesis is also linked to $\mathrm{pH}_{\mathrm{CF}}$ regulation, because $\mathrm{pH}_{\mathrm{CF}}$ is elevated in light relative to dark conditions [2]. Respiration rate may also be a factor effecting $\mathrm{pH}_{\mathrm{CF}}$, because many studies suggest that respiratory $\mathrm{CO}_{2}$ is a major source of DIC used in coral calcification [12,14-16].

Previous research on the influence of seawater environmental parameters on $\mathrm{pH}_{\mathrm{CF}}$ has almost exclusively focused on seawater $\mathrm{pH}$. This includes palaeoenvironmental research that has sought to determine the relationship between seawater $\mathrm{pH}$ and $\mathrm{pH}_{\mathrm{CF}}$ to better constrain the use of isotopic signatures in coral skeletons as indicators of seawater $\mathrm{pH}$ in earth's history [17-19]. It also includes a number of studies that have characterized how seawater $\mathrm{pH}$ affects $\mathrm{pH}_{\mathrm{CF}}$, in order to gain a better physiological understanding of how ocean acidification, which is considered to be one of the major environmental challenge to coral reefs, impacts coral calcification $[3,9,11]$. A decrease in seawater $\mathrm{pH}$ associated with ocean acidification can depress intracellular $\mathrm{pH}\left(\mathrm{pH}_{\mathrm{i}}\right)$ in calicoblastic cells and $\mathrm{pH}_{\mathrm{CF}}$, leading to a decrease in $\mathrm{CF}$ $\Omega_{\text {arag }}$ and declines in coral calcification rate [9]. Indeed, recent papers have linked the capacity of corals to regulate $\mathrm{pH}_{\mathrm{CF}}$ with the low sensitivity of some scleractinians to ocean acidification $[9,11]$.

While much attention has been paid to seawater $\mathrm{pH}$, experiments have not yet been conducted on the influence of other seawater carbonate chemistry parameters on $\mathrm{pH}_{\mathrm{CF}}$. This is surprising given the potential role of several carbonate chemistry parameters in $\mathrm{pH}_{\mathrm{CF}}$ regulation. For example, changes in seawater [DIC] and the concentrations of its components $\mathrm{CO}_{2}, \mathrm{HCO}_{3}^{-}$and $\mathrm{CO}_{3}^{2-}$ are likely to be of significance, because DIC species have integral roles in acid-base regulation of both cells and extracellular fluids in most organisms [20] (regardless of whether they engage in calcification). Furthermore, the total alkalinity $\left[\mathrm{A}_{\mathrm{T}}\right]$ of seawater, which describes the buffering capacity of seawater to $\mathrm{pH}$ change, is also potentially important for the buffering of protons removed from the CF. At a wider physiological level, seawater carbonate chemistry can affect processes such as photosynthesis and calcification that may themselves have a bearing on $\mathrm{pH}_{\mathrm{CF}}$. Indeed, previous studies have demonstrated that calcification rates are affected by seawater [DIC] and $\left[\mathrm{A}_{\mathrm{T}}\right]$ 
[21-25], and it is also known that coral photosynthetic rates respond to seawater [DIC] $[25,26]$. All these reasons suggest that $\mathrm{pH}_{\mathrm{CF}}$ may not simply be controlled by the $\mathrm{pH}$ gradient between the $\mathrm{CF}$ and the surrounding seawater.

Here, we test the hypothesis that variation in seawater [DIC] and $\left[\mathrm{A}_{\mathrm{T}}\right]$ impacts $\mathrm{pH}$ regulation of the $\mathrm{CF}$ in the scleractinian Stylophora pistillata, which in turn affects calcification rates. We manipulated seawater carbonate chemistry to modify seawater $[\mathrm{DIC}]$ and $\left[\mathrm{A}_{\mathrm{T}}\right]$ (i.e. our treatment levels) while maintaining seawater $\mathrm{pH}$ constant, thereby creating the potential to experimentally distinguish the effects of varying seawater [DIC] and $\left[\mathrm{A}_{\mathrm{T}}\right]$ from varying seawater $\mathrm{pH}$ on the $\mathrm{pH}_{\mathrm{CF}}$ in the corals. Under these conditions, we measured $\mathrm{pH}_{\mathrm{CF}}$ in vivo by confocal microscopy, and assessed calcification in the light and dark. Additionally, we sought to gain insights into the physiological mechanisms underlying how $\mathrm{pH}_{\mathrm{CF}}$ is regulated, through measurements of rates of photosynthesis, respiration and $\mathrm{pH}_{\mathrm{i}}$ of the calicoblastic cells (measured by confocal microscopy).

\section{Material and methods}

\section{(a) Experimental set-up}

Coral samples were prepared from three colonies maintained in the coral culture facilities at the Centre Scientifique de Monaco. Samples were prepared as nubbins (22 per colony) suspended on monofilament threads or microcolonies grown laterally on glass coverslips (eight per colony) according to methods given in [20]. Four experimental treatments were maintained total scale $\mathrm{pH}\left(\mathrm{pH}_{\mathrm{T}}\right)$ at approximately 7.9 , with manipulated [DIC] and $\left[\mathrm{A}_{\mathrm{T}}\right]$ using combinations of $\mathrm{CO}_{2}$-free air, pure $\mathrm{CO}_{2}, 1 \mathrm{M}$ $\mathrm{HCl}$ and $1 \mathrm{M} \mathrm{NaOH}$ (electronic supplementary material table S1). Throughout the manuscript, these treatments are referred to as 'very low', 'low', 'ambient' and 'high' [DIC] and $\left[\mathrm{A}_{\mathrm{T}}\right]$.

Eight nubbins mounted on threads and three microcolonies on coverslips were randomly selected and placed in each of eight 201 tanks for DIC treatments and were maintained in the aquaria during 15 days. Details of the aquarium conditions, manipulations of DIC and monitoring of carbonate chemistry are provided in the electronic supplementary material.

\section{(b) Calcification}

Calcification of the coral nubbins was measured using two techniques: buoyant weight was used to evaluate calcification over the two weeks of incubation, and the alkalinity anomaly technique [27] was used to differentiate short-term (approx. $30 \mathrm{~min}$ ) calcification in the light and dark at the end of the two week incubation period. Buoyant weight $( \pm 1 \mathrm{mg})$ was recorded before and after the 15 day incubation, using eight nubbins per DIC treatment, and the difference between the two was converted to dry weight, using an aragonite density of $2.93 \mathrm{~g} \mathrm{~cm}^{-3}$.

Light and dark calcification were estimated on three coral pieces per treatment. After 10 days of incubation, nubbins were chosen randomly from the tanks and placed in separate $100 \mathrm{ml}$ glass beakers containing seawater from the respective incubation tanks. Light incubations were performed in the morning after corals were exposed to a minimum of $1 \mathrm{~h}$ of light. Dark incubations were performed at the end of the night on corals that were acclimated to darkness for more than $8 \mathrm{~h}$. Calcification rates determined by buoyant weighing and alkalinity anomaly were normalized to surface area, estimated using the wax dipping method [28].

\section{(c) Experimental conditions for confocal microscopy}

Measurements of $\mathrm{pH}_{\mathrm{CF}}$ (=subcalicoblastic medium) and $\mathrm{pH}_{\mathrm{i}}$ of the calcifying cells in the light and dark were made by inverted confocal microscopy (Leica SP5, Germany) as described previously [9]. Briefly, samples that had been grown laterally on glass coverslips were fitted in semi-closed perfusion chambers ( $4 \mathrm{~cm}$ internal diameter; PeCon, Germany), mounted on the confocal microscope and supplied with seawater drawn from the desired incubation treatment (renewal rate of $50 \% \mathrm{~min}^{-1}$ in $2.5 \mathrm{ml}$ ). Colony sizes were restricted to $1 \mathrm{~cm}^{2}$ in surface area, irradiance was provided by fibre optic light source (Philips 21 V 150-W halogen bulb) and temperature was maintained at $25^{\circ} \mathrm{C}$. Prior optimization of seawater flow rates and colony size has demonstrated that carbonate chemistry remains constant in the perfusion under these conditions $[2,9,29]$ (see discussion of the experimental design in the electronic supplementary material).

\section{(d) Analysis of $\mathrm{pH}_{\mathrm{CF}}$ and $\mathrm{pH}_{\mathrm{i}}$ of calicoblastic cells}

Confocal $\mathrm{pH}$ measurements were made using ratiometric analysis of two forms of the dual emission $\mathrm{pH}$-sensitive dye SNARF-1 (Invitrogen) according to methods published previously [2,9]. After being transferred from the treatment aquaria directly to the microscope, samples were first perfused with seawater from the desired experimental treatment for $10 \mathrm{~min}$ in either the light or dark. For $\mathrm{pH}_{\mathrm{CF}}$, samples were then perfused with seawater from the desired treatment containing $45 \mu \mathrm{M}$ cell-impermeable SNARF-1 for a 5 min loading period, before making five measurements of $\mathrm{pH}_{\mathrm{CF}}$ during a 10 min time window in light or dark. $\mathrm{pH}$ measurements were also taken in the seawater surrounding the corals in the perfusion chamber to confirm seawater $\mathrm{pH}$ remained stable during confocal analysis and that it remained the same between treatments.

For measurements of $\mathrm{pH}_{\mathrm{i}}$ of calicoblastic cells, the procedure involved $10 \mathrm{~min}$ of dye loading by perfusion with seawater containing $10 \mu \mathrm{M}$ cell-permeable SNARF-1 AM, followed by 10 min of seawater perfusion, during which $\mathrm{pH}_{\mathrm{i}}$ measurements were taken to check $\mathrm{pH}_{\mathrm{i}}$ was stable.

Calibration of intracellular SNARF-1 AM and extracellular (seawater and CF) SNARF-1 to $\mathrm{pH}$ was performed as described previously [16] to the National Bureau of Standards (NBS) $\mathrm{pH}$ scale and total scale $\mathrm{pH}$, respectively.

$\mathrm{pH}_{\mathrm{CF}}$ and calicoblastic cell $\mathrm{pH}_{\mathrm{i}}$ measurements were carried out at $40 \times$ magnification by excitation at $543 \mathrm{~nm}$ at $30 \%$ laser intensity, and fluorescence captured at emission wavelengths of $585 \pm 10 \mathrm{~nm}$ and $640 \pm 10 \mathrm{~nm}$. For each measurement, several optical sections were captured in a Z-stack, with an acquisition time of approximately $10 \mathrm{~s}$. $\mathrm{pH}_{\mathrm{CF}}$ was measured in light and dark conditions in six samples from each treatment. Calicoblastic cell $\mathrm{pH}_{\mathrm{i}}$ was measured in three colonies from the very low, ambient and high $[\mathrm{DIC}]$ and $\left[\mathrm{A}_{\mathrm{T}}\right]$ treatments.

\section{(e) Photosynthesis and respiration}

Rates of net photosynthesis $\left(P_{\mathrm{n}}\right)$ and respiration $(R)$ were assessed at 0 and $250 \mu \mathrm{mol}$ quanta $\mathrm{m}^{-2} \mathrm{~s}^{-1}$ on five nubbins per treatment in $50 \mathrm{ml}$ glass chambers. Chambers were equipped with a Unisense optode (oxygen-sensitive minisensor) connected to the Oxy-4 software (Chanel fibreoptic oxygen meter, Presens, Regensburg, Germany). The optodes were calibrated before each experiment against air-saturated (by bubbling) and nitrogen-saturated seawater (for the $100 \%$ and $0 \%$ oxygen, respectively). Stir bars were used to continuously create turbulent conditions in the chambers. $P_{\mathrm{n}}$ and $R$ were calculated by regressing oxygen flux against time, and were corrected by control incubation performed with empty chambers. Gross photosynthesis was calculated by adding the absolute value of $R$ to $P_{\mathrm{n}}$. At the end of each incubation, nubbins were frozen $\left(-20^{\circ} \mathrm{C}\right)$ before determining Symbiodinium densities, and total chlorophyll concentrations [30].

All the data presented in the manuscript were deposited in the PANGAEA database [31]. 

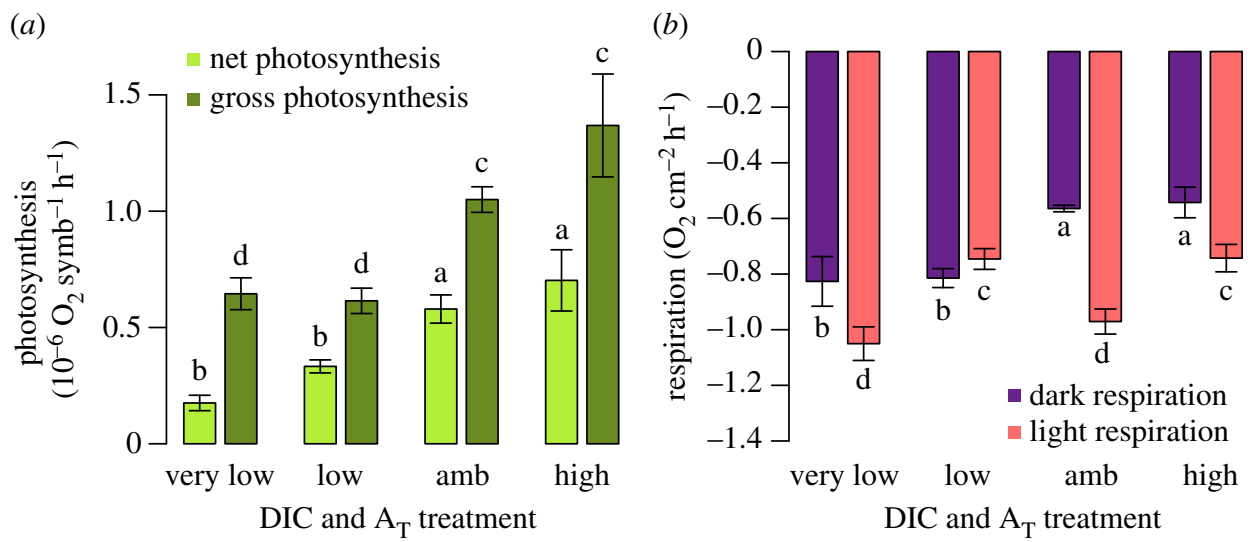

Figure 2. Photosynthesis and respiration (mean \pm s.e.) of S. pistillata incubated at constant $\mathrm{pH}_{\mathrm{T}}$ (approx. 7.9) and varying dissolved inorganic carbon concentration [DIC] and total alkalinity $\left[A_{T}\right]$. ([DIC] was approximately $800,1500,2200,2900 \mu \mathrm{mol} \mathrm{kg}^{-1}$ in the very low, low, amb and high treatments, respectively). (a) Net photosynthesis and gross photosynthesis normalized by the Symbiodinium density measured at the end of the two week incubation. (b) Light and dark respiration normalized by the surface area of organisms. Columns with the same letters were not significantly different (post hoc analyses). (Online version in colour.)

(a)

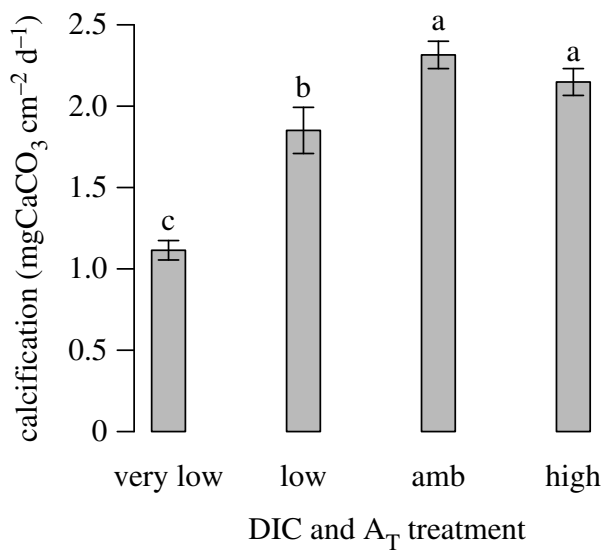

(b)

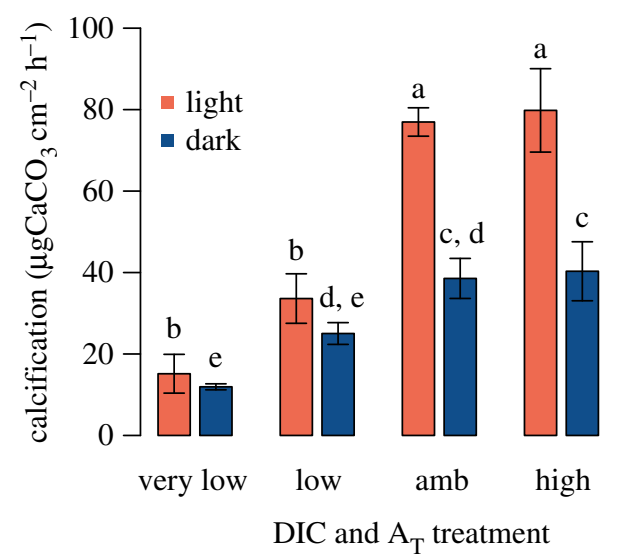

Figure 3. Calcification rates (mean \pm s.e.) of S. pistillata at constant $\mathrm{pH}_{\mathrm{T}}$ (approx. 7.9) and varying [DIC] and [ $\left.\mathrm{A}_{T}\right]$. ([DIC] was approximately 800, 1500, 2200, $2900 \mu \mathrm{mol} \mathrm{kg}^{-1}$, in the very low, low, amb and high treatments, respectively). (a) Net calcification measured by the buoyant weight technique over the two week incubation. (b) Net calcification measured in the light and the dark at the end of the incubations using the alkalinity anomaly technique. Columns with the same letters were not significantly different (post hoc analyses). (Online version in colour.)

\section{Results}

\section{(a) Carbonate chemistry}

Carbonate chemistry in the tanks was precisely regulated across all treatments, and tanks were accurately duplicated within treatments (electronic supplementary material, table S1). Seawater $\mathrm{pH}_{\mathrm{T}}$ was maintained close to the $\mathrm{pH}$ in the ambient treatment $(7.89 \pm 0.1)$, with mean values of $7.92 \pm 0.1,7.94 \pm$ 0.2 and $7.91 \pm 0.3$ in the very low, low and high [DIC] and $\left[\mathrm{A}_{\mathrm{T}}\right]$ treatments, respectively $( \pm$ s.e., $n=15$, electronic supplementary material, table S1). [DIC] was maintained at $847 \pm 57,1554 \pm 47,2219 \pm 10$ and $2968 \pm 39 \mu \mathrm{mol} \mathrm{kg}^{-1}$ in the very low, low, ambient and high [DIC] treatments (respectively), which corresponded to $\left[\mathrm{A}_{\mathrm{T}}\right]$ values of $1001 \pm 30,1775 \pm$ $31,2461 \pm 5$ and $3278 \pm 19 \mu \mathrm{mol} \mathrm{kg}^{-1}$ (mean \pm s.e., $n=15$, electronic supplementary material, table S1).

\section{(b) Photosynthesis — respiration}

In the following section, photosynthesis was normalized to Symbiodinium cells to assess the functioning of the symbionts under the different $[\mathrm{DIC}]$ and $\left[\mathrm{A}_{\mathrm{T}}\right]$ treatments. Respiration was normalized to surface area to assess both the host's and the symbionts' responses to the treatments. Symbiodiniumnormalized net photosynthesis $\left(P_{\mathrm{n}}\right)$ was maximal at ambient and high $[\mathrm{DIC}]$ and $\left[\mathrm{A}_{\mathrm{T}}\right]$ (figure $2 a$, light green). There was an effect of treatment on Symbiodinium-normalized $P_{\mathrm{n}} \quad(p<$ 0.001 ), with $P_{\mathrm{n}}$ increasing with $[\mathrm{DIC}]$ and $\left[\mathrm{A}_{\mathrm{T}}\right]$ (figure $2 a$ ). Gross photosynthesis $\left(P_{\mathrm{g}}\right)$ followed similar trends, with a significant effect of treatment $(p<0.001)$ and greatest values for Symbiodinium-normalized rates at ambient and high [DIC] and $\left[\mathrm{A}_{\mathrm{T}}\right]$ treatments (figure $2 a$ ).

Surface area-normalized dark respiration $\left(R_{\mathrm{d}}\right)$ was affected by treatment $(p=0.004)$ and slightly decreased with increasing $[\mathrm{DIC}]$ and $\left[\mathrm{A}_{\mathrm{T}}\right]$ (figure $2 b$ ). Surface area-normalized respiration in the light $\left(R_{\mathrm{l}}\right)$ was affected by treatment when normalized to area $(p<0.001$; figure $2 b)$ although there was no overall decreasing or increasing trend across [DIC] and $\left[\mathrm{A}_{\mathrm{T}}\right]$ treatments.

\section{(c) Calcification}

Buoyant weight analysis of S. pistillata was conducted to provide an integrated measurement of net calcification (dry weight) in the light and dark over the 15 days period (figure $3 a$ ). Treatment affected calcification (ANOVA, $F_{3,36}=$ 

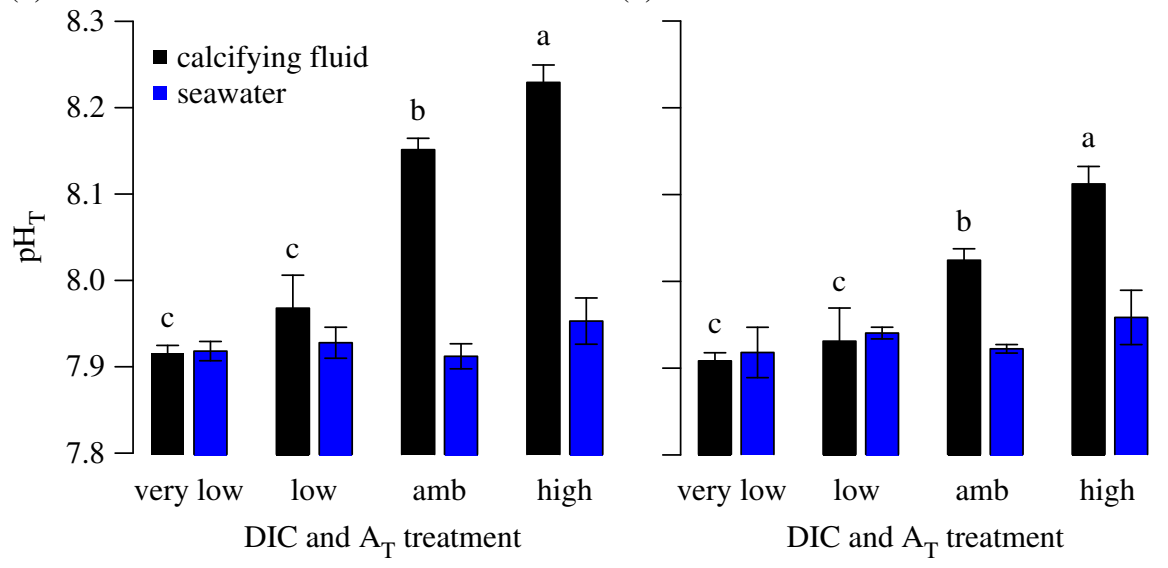

Figure 4. Confocal microscopy pH measurements (mean \pm s.e.) made on organisms maintained under constant $\mathrm{pH}_{\mathrm{T}}$ (approx. 7.9) and varying dissolved inorganic carbon concentration $[\mathrm{DIC}]$ and $[\mathrm{AT}]$. ([DIC] was approximately $800,1500,2200,2900 \mu \mathrm{mol} \mathrm{kg}^{-1}$, in the very low, low, amb and high treatments, respectively). Measurements were done in the light $(a)$ and dark $(b)$ in the calcifying fluid and the seawater. Columns with the same letters were not significantly different (post hoc analyses). (Online version in colour.)

30.04, $p<0.001$ ), with calcification increasing with [DIC] and $\left[\mathrm{A}_{\mathrm{T}}\right]$ from the very low to the ambient treatment (figure $3 a$ ). Post hoc analyses showed that calcification in the very low and low $[\mathrm{DIC}]$ and $\left[\mathrm{A}_{\mathrm{T}}\right]$ differed significantly from all the other treatments $(p<0.01)$.

Net light calcification of $S$. pistillata was impacted by treatment, with a maximum of $79 \pm 10 \mu \mathrm{g} \mathrm{CaCO}_{3} \mathrm{~cm}^{-2} \mathrm{~h}^{-1}$ in the high $[\mathrm{DIC}]$ and $\left[\mathrm{A}_{\mathrm{T}}\right]$ treatment, and a minimum of $15 \pm$ $5 \mu \mathrm{g} \mathrm{CaCO}_{3} \mathrm{~cm}^{-2} \mathrm{~h}^{-1}$ in the very low [DIC] and $\left[\mathrm{A}_{\mathrm{T}}\right]$ treatment (figure $3 b$ ). Treatment affected net calcification in the light (ANOVA, $p<0.001$ ), and post hoc analyses revealed that calcification differed between treatments $(p<0.01)$, except between the very low and low $[\mathrm{DIC}]$ and $\left[\mathrm{A}_{\mathrm{T}}\right]$ treatments $(p=0.326)$ and between the ambient and high [DIC] and $\left[\mathrm{A}_{\mathrm{T}}\right]$ treatments $(p=0.994)$.

Similarly, maximal net calcification rates in the dark were recorded in the high and ambient $[\mathrm{DIC}]$ and $\left[\mathrm{A}_{\mathrm{T}}\right]$ treatment, whereas minimal calcification $\left(11 \pm 1 \mu \mathrm{g} \mathrm{CaCO}_{3} \mathrm{~cm}^{-2} \mathrm{~h}^{-1}\right)$ was measured in the very low $[\mathrm{DIC}]$ and $\left[\mathrm{A}_{\mathrm{T}}\right]$ treatment (figure $3 b)$. Treatment affected calcification in the dark $(p<$ $0.001)$, with increasing $[\mathrm{DIC}]$ and $\left[\mathrm{A}_{\mathrm{T}}\right]$ stimulating dark calcification. Post hoc analyses demonstrated that the very low treatment differed from the ambient and high [DIC] and $\left[\mathrm{A}_{\mathrm{T}}\right]$, and the low $[\mathrm{DIC}]$ and $\left[\mathrm{A}_{\mathrm{T}}\right]$ differed from the high [DIC] and $\left[\mathrm{A}_{\mathrm{T}}\right]$ treatment $(p<0.002)$.

\section{(d) Calcifying fluid pH}

Coral samples were mounted in a perfusion chamber and analysed by confocal microscopy and the fluorescent $\mathrm{pH}$ dye SNARF-1 to determine $\mathrm{pH}_{\mathrm{CF}}$. The experimental set-up also allowed confocal measurements of $\mathrm{pH}$ to be taken in the seawater flowing through the perfusion chamber to confirm that seawater $\mathrm{pH}$ was consistent among treatments (figure 4).

$\mathrm{pH}_{\mathrm{CF}}$ varied across the treatments during the light and dark $(p<0.001)$, and was more elevated at higher [DIC] and $\left[\mathrm{A}_{\mathrm{T}}\right]$ (figure $4 a, b$ ). In the light, $\mathrm{pH}_{\mathrm{CF}}$ varied from $7.92 \pm 0.01$ in the very low $[\mathrm{DIC}]$ and $\left[\mathrm{A}_{\mathrm{T}}\right]$ treatment to $8.23 \pm 0.02$ in the high $[\mathrm{DIC}]$ and $\left[\mathrm{A}_{\mathrm{T}}\right]$ treatment. Post hoc analyses revealed that $\mathrm{pH}_{\mathrm{CF}}$ differed between treatments, except between the very low and low $[\mathrm{DIC}]$ and $\left[\mathrm{A}_{\mathrm{T}}\right](p=0.395)$. In the dark, $\mathrm{pH}_{\mathrm{CF}}$ varied from $7.91 \pm 0.02$ at very low [DIC], to $8.11 \pm 0.01$ at high $[\mathrm{DIC}]$ and $\left[\mathrm{A}_{\mathrm{T}}\right]$. Similar to $\mathrm{pH}_{\mathrm{CF}}$ in the

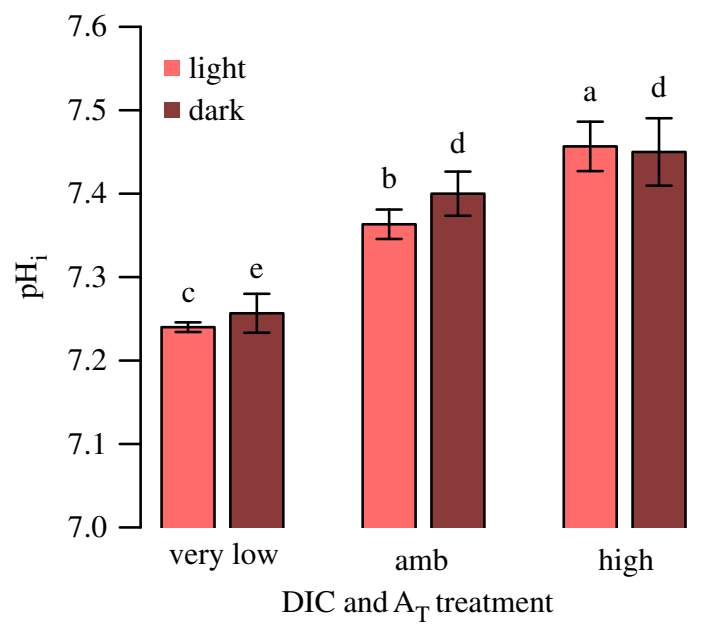

Figure 5. Confocal microscopy measurements of the $\mathrm{pH}$ in the calicoblastic cells $\left(\mathrm{pH}_{\mathrm{i}}\right)$ (mean \pm s.e.) of $\mathrm{S}$. pistillata maintained under constant $\mathrm{pH}_{\mathrm{T}}$ (approx. 7.9) and very low $[\mathrm{DIC}]$ and $\left[\mathrm{A}_{\mathrm{T}}\right]$ (very low, DIC approx. $\left.800 \mu \mathrm{mol} \mathrm{kg}^{-1} ; \mathrm{A}_{\mathrm{T}}\right]$ approx. $\left.1000 \mu \mathrm{mol} \mathrm{kg}{ }^{-1}\right)$, ambient $\mathrm{DIC}$ and $\left[\mathrm{A}_{\mathrm{T}}\right]$ (amb; DIC approx. $2200 \mu \mathrm{mol} \mathrm{kg}^{-1}$; [A $\left.\mathrm{A}_{\mathrm{T}}\right]$ approx. $2500 \mu \mathrm{mol} \mathrm{kg}{ }^{-1}$ ), and high DIC (high, DIC approx. $2900 \mu \mathrm{mol} \mathrm{kg}^{-1} ; \quad\left[A_{T}\right]$ approx. $3300 \mu \mathrm{mol} \mathrm{kg}{ }^{-1}$ ). Measurements were done in the light and the dark. Columns with the same letters were not significantly different (post hoc analyses). (Online version in colour.)

light, post hoc analyses showed that $\mathrm{pH}_{\mathrm{CF}}$ in the dark differed between treatments, except between the very low and low $[\mathrm{DIC}]$ and $\left[\mathrm{A}_{\mathrm{T}}\right](p=0.904)$.

\section{(e) Calicoblastic cell $\mathrm{pH}_{\mathrm{i}}$}

$\mathrm{pH}_{\mathrm{i}}$ was measured in the high, ambient and very low DIC and $\left[\mathrm{A}_{\mathrm{T}}\right]$ treatments (figure 5). $\mathrm{pH}_{\mathrm{i}}$ varied according to [DIC] and $\left[\mathrm{A}_{\mathrm{T}}\right]$ in both light and darkness $(p<0.001$ and $p=0.011$ in light and darkness, respectively) with $\mathrm{pH}_{\mathrm{i}}$ decreasing with decreasing $[\mathrm{DIC}]$ and $\left[\mathrm{A}_{\mathrm{T}}\right]$.

\section{Discussion}

Determining the factors that control $\mathrm{pH}$ regulation of the $\mathrm{CF}$ is a critical step towards a better mechanistic understanding of 
coral calcification physiology, and identifying why corals are sensitive to changes in seawater carbonate chemistry. Previous investigations into $\mathrm{pH}_{\mathrm{CF}}$ have focused on the influence of seawater $\mathrm{pH}$ on $\mathrm{pH}_{\mathrm{CF}}$, and no attention has been paid to other seawater carbonate parameters. Here we maintained seawater $\mathrm{pH}$ constant, while modifying seawater carbonate chemistry through a manipulation of $\left[\mathrm{A}_{\mathrm{T}}\right]$ and $[\mathrm{DIC}]$, which resulted in variation in the concentration of the components of seawater $\mathrm{DIC}$, namely $\mathrm{CO}_{2}, \mathrm{HCO}_{3}^{-}$and $\mathrm{CO}_{3}^{2-}$ (electronic supplementary material, table $\mathrm{S} 1$ ). $\mathrm{pH}_{\mathrm{CF}}$ varied across the treatments, displaying a positive relationship with increasing [DIC] and $\left[\mathrm{A}_{\mathrm{T}}\right]$ despite external seawater $\mathrm{pH}$ remaining constant. Notably, $\mathrm{pH}_{\mathrm{CF}}$ was not regulated above the surrounding seawater $\mathrm{pH}$ by corals in the low and very low $[\mathrm{DIC}]$ and $\left[\mathrm{A}_{\mathrm{T}}\right]$ treatments. Our findings demonstrate that seawater $\mathrm{pH}$ is not the only driver of $\mathrm{pH}_{\mathrm{CF}}$.

\section{(a) Influence of photosynthesis and respiration on $\mathrm{pH}_{\mathrm{CF}}$} We analysed photosynthesis and respiration, because previous research suggests that both physiological parameters are likely to have major roles in influencing $\mathrm{pH}_{\mathrm{CF}}$ levels $[2,14]$. Studies have shown that photosynthesis increases $\mathrm{pH}_{\mathrm{CF}}$ in the light versus dark $[2,10]$. The data in this study are consistent with these previous studies, because under ambient $[\mathrm{DIC}]$ and $\left[\mathrm{A}_{\mathrm{T}}\right], \mathrm{pH}_{\mathrm{CF}}$ was higher in the light than in the dark, and when net photosynthetic rates decreased in low and very low $[\mathrm{DIC}]$ and $\left[\mathrm{A}_{\mathrm{T}}\right]$ treatments, there was a concomitant drop in $\mathrm{pH}_{\mathrm{CF}}$. It is possible that the drop in photosynthetic rate occurred owing to DIC-limitation, because corals use external seawater DIC as the principal source of carbon for photosynthesis [14]. Overall, this could point to a mechanism by which seawater [DIC] modulates $\mathrm{pH}_{\mathrm{CF}}$ by affecting photosynthetic rate. Although this mechanism may provide a partial explanation for the response of $\mathrm{pH}_{\mathrm{CF}}$ to seawater [DIC] and $\left[\mathrm{A}_{\mathrm{T}}\right]$ treatments in the light, it does not, however, explain the dark pattern and why $\mathrm{pH}_{\mathrm{CF}}$ increased in high $[\mathrm{DIC}]$ and $\left[\mathrm{A}_{\mathrm{T}}\right]$ treatment relative to ambient $[\mathrm{DIC}]$ and $\left[\mathrm{A}_{\mathrm{T}}\right]$, despite net photosynthetic rates remaining unchanged.

In the case of respiration, previous studies indicate that DIC derived from coral respiration accounts for a large portion of the DIC used in coral calcification [14,16]. It follows, therefore, that variation in production of respiratory $\mathrm{CO}_{2}$ may have an effect on $\mathrm{pH}_{\mathrm{CF}}$. Reductions in $\mathrm{pH}_{\mathrm{CF}}$ at low and very low [DIC] and $\left[\mathrm{A}_{\mathrm{T}}\right]$ observed in darkness are consistent with this possibility, because respiration rates were significantly elevated in these treatments relative to ambient and high DIC and $\left[\mathrm{A}_{\mathrm{T}}\right]$ levels. This could suggest a mechanism where at lower seawater $[\mathrm{DIC}]$ and $\left[\mathrm{A}_{\mathrm{T}}\right]$, increased respiration led to higher rates of $\mathrm{CO}_{2}$ diffusion from calicoblastic cells into the CF with an acidifying effect. Under such a scenario, cellular mechanisms of $\mathrm{pH}_{\mathrm{CF}}$ regulation (e.g. previously proposed $\mathrm{Ca}^{2+}$ ATPase activity) appeared not to have prevented $\mathrm{CF}$ acidosis. However, changes in respiration rates do not explain increases in $\mathrm{pH}_{\mathrm{CF}}$ that occurred at high [DIC] and $\left[\mathrm{A}_{\mathrm{T}}\right]$ in darkness, as respiration rates were the same in the ambient and high $[\mathrm{DIC}]$ and $\left[\mathrm{A}_{\mathrm{T}}\right]$ treatments.

\section{(b) Influence of $\mathrm{pH}_{\mathrm{i}}$ of calcifying cells on $\mathrm{pH}_{\mathrm{CF}}$}

Variation in rates of photosynthesis and respiration may have contributed to the observed response of $\mathrm{pH}_{\mathrm{CF}}$ to changes in seawater carbonate chemistry associated with shifts in [DIC] and $\left[\mathrm{A}_{\mathrm{T}}\right]$, but these parameters do not explain certain aspects of our data. As noted in $\S 4 \mathrm{a}, \mathrm{pH}_{\mathrm{CF}}$ was higher in high [DIC] and $\left[\mathrm{A}_{\mathrm{T}}\right]$ treatments relative to ambient $[\mathrm{DIC}]$ and $\left[\mathrm{A}_{\mathrm{T}}\right]$, with no concomitant change in photosynthesis or respiration. Furthermore, in low and very low $[\mathrm{DIC}]$ and $\left[\mathrm{A}_{\mathrm{T}}\right]$ treatments, $\mathrm{pH}_{\mathrm{CF}}$ was no longer regulated above seawater $\mathrm{pH}$ in either light or dark conditions. These data suggest that seawater carbonate chemistry parameters may affect $\mathrm{pH}_{\mathrm{CF}}$ by an additional mechanism not directly related to photosynthesis or respiration.

It is unlikely that this mechanism involves seawater leakage (e.g. by paracellular transport) into the $\mathrm{CF}$ exerting direct control of $\mathrm{pH}_{\mathrm{CF}}$, because maintaining elevated $\mathrm{pH}$ under elevated $[\mathrm{DIC}]$ and $\left[\mathrm{A}_{\mathrm{T}}\right]$, with higher buffering capacity, is chemically more challenging than at low $[\mathrm{DIC}]$ and $\left[\mathrm{A}_{\mathrm{T}}\right]$ [32]. Thus, if the mechanism by which corals regulate $\mathrm{pH}_{\mathrm{CF}}$ remains the same between treatments, we would not expect to see decreases in $\mathrm{pH}_{\mathrm{CF}}$ in the low and very low [DIC] and $\left[\mathrm{A}_{\mathrm{T}}\right]$ treatments relative to high $[\mathrm{DIC}]$ and $\left[\mathrm{A}_{\mathrm{T}}\right]$.

Instead, our calicoblastic cell $\mathrm{pH}_{\mathrm{i}}$ data point to another candidate mechanism by which $\mathrm{pH}_{\mathrm{CF}}$ is affected, involving an effect of changes in seawater carbonate chemistry on calicoblastic $\mathrm{pH}_{\mathrm{i}}$. Calicoblastic $\mathrm{pH}_{\mathrm{i}}$ decreased in parallel with changes in seawater carbonate chemistry associated with decreases in seawater $[\mathrm{DIC}]$ and $\left[\mathrm{A}_{\mathrm{T}}\right]$ at constant $\mathrm{pH}$. These data indicate that the concentration of one or more DIC species (e.g. $\mathrm{CO}_{2}, \mathrm{HCO}_{3}^{-}$or $\mathrm{CO}_{3}^{2-}$ ) or seawater $\mathrm{A}_{\mathrm{T}}$ itself has a direct bearing on $\mathrm{pH}_{\mathrm{i}}$ regulation in these cells. Although the available data in our paper and in the literature provide little insight into identifying which carbonate chemistry parameter is responsible for the changes in calicoblastic cell $\mathrm{pH}_{\mathrm{i}}$ disruption to $\mathrm{pH}_{\mathrm{i}}$ impairs cellular processes including the functioning of membrane transporters [33]. Therefore, it follows that a decrease in calicoblastic cell $\mathrm{pH}_{\mathrm{i}}$ may directly impinge on the ability of this tissue layer to regulate $\mathrm{pH}$ of the $\mathrm{CF}$, contributing to the observed declines in $\mathrm{pH}_{\mathrm{CF}}$ in the lower [DIC] and $\left[\mathrm{A}_{\mathrm{T}}\right]$ treatments. Indeed, previous research involving seawater acidification has also argued that decreases in $\mathrm{pH}_{\mathrm{i}}$ of calicoblastic cells may lead to decreases in $\mathrm{pH}_{\mathrm{CF}}$ [9].

Determining the effects of carbonate chemistry on both calcifying cell $\mathrm{pH}_{\mathrm{i}}$ and $\mathrm{pH}_{\mathrm{CF}}$ will depend crucially on a better understanding of ion transport from seawater across the coral tissues. Currently, the literature on this subject is not clear, because certain previous studies have pointed to a largely unrestricted exchange of ions between the CF and the surrounding seawater [5], whereas other studies have pointed to a more restricted exchange of ions mediated by transcellular transport mechanisms and septate junctions between cells $[6,7]$.

\section{(c) Calcification and calcifying fluid $\Omega$}

Several studies manipulating seawater carbonate chemistry have found that varying $[\mathrm{DIC}]$ and $\left[\mathrm{A}_{\mathrm{T}}\right]$ affects coral calcification rates [21-23]. These studies include the work of Jury et al. [21] and Schneider \& Erez [25], who recorded a strong decline in calcification rates at constant ambient seawater $\mathrm{pH}$ over a decrease in seawater [DIC] and $\left[\mathrm{A}_{\mathrm{T}}\right]$ similar to that of this study. Schneider \& Erez [25] also demonstrated a decrease in calcification with [DIC] when $\mathrm{pH}$ was held constant. These results have been interpreted to mean that decreases in seawater [DIC] restrict the supply of inorganic carbon as a reactant in the calcification reaction [21-25]. 
(a)

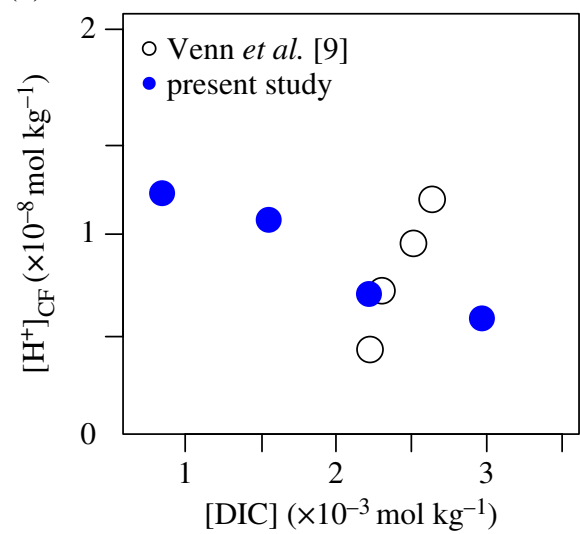

(c)

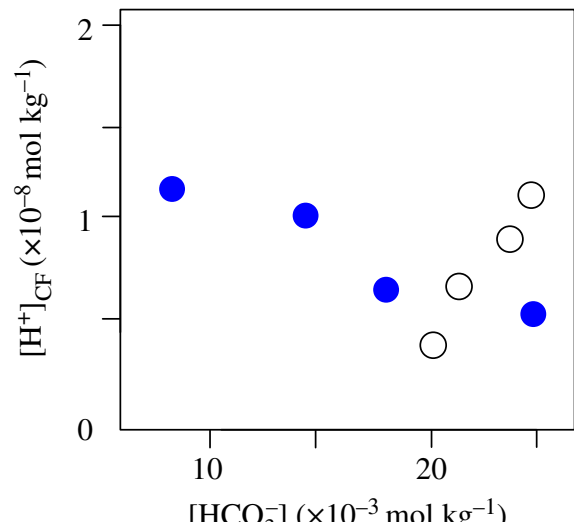

(e)

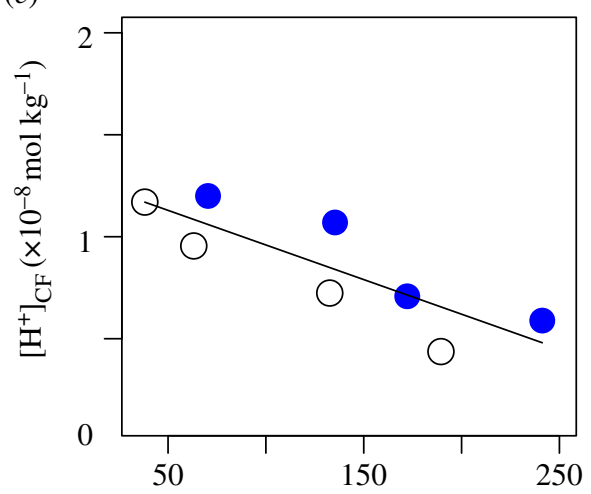

$[\mathrm{DIC}] /\left[\mathrm{H}^{+}\right] \times 10^{3}$ (b)

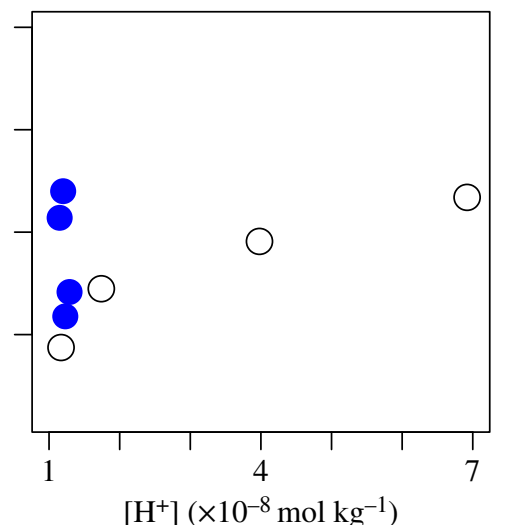

(d)

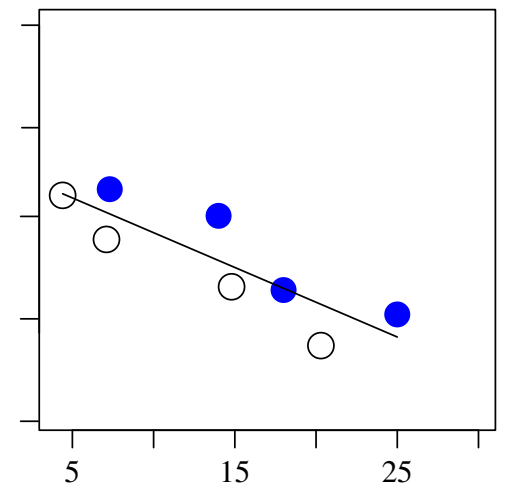

$\left[\mathrm{CO}_{3}^{2-}\right]\left(\times 10^{-5} \mathrm{~mol} \mathrm{~kg}^{-1}\right)$

$(f)$

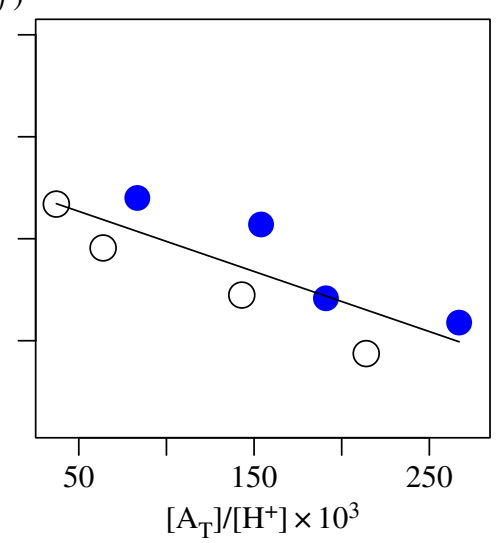

Figure 6. Relationship between the proton concentration in the calcifying fluid $\left(\left[\mathrm{H}^{+}\right]_{\mathrm{CF}}\right)$ and various parameters of the carbonate chemistry. Data from this study (filled circles) were combined with data from Venn et al. [9] (open circles) to compare $\mathrm{CO}_{2}$-driven decreases in seawater pH with relatively small increases in seawater $[\mathrm{DIC}]$ and no change in $\left[\mathrm{A}_{\mathrm{T}}\right]$ with large change of $[\mathrm{DIC}]$ and $\left[\mathrm{A}_{\mathrm{T}}\right]$ at constant $\mathrm{pH}$. $\left[\mathrm{H}^{+}\right]_{\mathrm{CF}}$ was plotted against $(a)$ seawater $[\mathrm{DIC}],(b)$ seawater $\left[\mathrm{H}^{+}\right]$, (c) seawater $\left[\mathrm{HCO}_{3}^{-}\right],(d)$ seawater $\left[\mathrm{CO}_{3}^{2-}\right],(e)$ the ratio $[\mathrm{DIC}] /\left[\mathrm{H}^{+}\right]$and $(f)$ the ratio $\left[\mathrm{A}_{\mathrm{T}}\right] /\left[\mathrm{H}^{+}\right]$. There were strong linear correlations of $\left[\mathrm{H}^{+}\right]_{\mathrm{CF}}$ with $\left[\mathrm{CO}_{3}^{2-}\right]$, the ratio $[\mathrm{DIC}] /\left[\mathrm{H}^{+}\right]$and the ratio $\left[\mathrm{A}_{\mathrm{T}}\right] /\left[\mathrm{H}^{+}\right]\left(R^{2}=0.71, p=0.010 ; R^{2}=0.75, p=0.006\right.$, and $R^{2}=0.68, p=0.012$, respectively). (Online version in colour.)

Our study provides a new, complementary perspective where changes in carbonate chemistry associated with shift in seawater $[\mathrm{DIC}]$ and $\left[\mathrm{A}_{\mathrm{T}}\right]$ also modulate $\mathrm{pH}_{\mathrm{i}}$ and $\mathrm{pH}_{\mathrm{CF}}$. As $\mathrm{pH}_{\mathrm{CF}}$ affects aragonite saturation state $\left(\Omega_{\text {arag }}\right)$ of the $\mathrm{CF}$, changes in $\mathrm{pH}_{\mathrm{CF}}$ are expected to correspond to changes in calcification rate. Our observations of decreased calcification rates of S. pistillata measured by buoyant weight and alkalinity anomaly methods are consistent with this expectation, as calcification rates follow a similar trend to $\mathrm{pH}_{\mathrm{CF}}$ in very low, low and ambient $[\mathrm{DIC}]$ and $\left[\mathrm{A}_{\mathrm{T}}\right]$ treatments under both light and dark conditions.

We note that there are differences between the patterns of $\mathrm{pH}_{\mathrm{CF}}$ and calcification, which suggest that $\mathrm{pH}_{\mathrm{CF}}$ is not the only factor influencing the calcification response to seawater
[DIC $]$ and $\left[\mathrm{A}_{\mathrm{T}}\right]$. For example, while calcification rates saturate at ambient and high [DIC] and $\left[\mathrm{A}_{\mathrm{T}}\right], \mathrm{pH}_{\mathrm{CF}}$ increased between ambient and high $[\mathrm{DIC}]$ and $\left[\mathrm{A}_{\mathrm{T}}\right]$. Similarly, a comparison between similar light and dark $\mathrm{pH}_{\mathrm{CF}}$ values (e.g. $\mathrm{pH}_{\mathrm{CF}} 8.15$ in the light at ambient [DIC] and $\left[\mathrm{A}_{\mathrm{T}}\right]$ versus $\mathrm{pH}_{\mathrm{CF}} 8.11$ in the dark in high $[\mathrm{DIC}]$ and $\left[\mathrm{A}_{\mathrm{T}}\right]$ ) does not yield similar calcification rates (light ambient $[\mathrm{DIC}]$ and $\left[\mathrm{A}_{\mathrm{T}}\right]$ calcification rates are two times higher than dark calcification rates at high [DIC] and $\left.\left[\mathrm{A}_{\mathrm{T}}\right]\right)$. This indicates that although regulation of $\mathrm{pH}_{\mathrm{CF}}$ is essential to provide a favourable physiochemical environment for $\mathrm{CaCO}_{3}$ precipitation, the physiology and biochemistry involved in the calcification process is complex [6] and involves additional factors that are likely to influence calcification rates. These include synthesis of the skeletal organic 
matrix by the calicoblastic cells partly from precursors produced by the coral's symbiotic algae [34]. The organic matrix serves to catalyse nucleation of aragonite crystals and potentially act as template for skeleton formation [6,35].

In addition to $\mathrm{pH}_{\mathrm{CF}}, \Omega_{\text {arag }}$ of the CF and calcification rates may also be determined by CF [DIC], but we are not able to determine this parameter from our data. Currently, the literature is divided over whether or not [DIC] is elevated in the $\mathrm{CF}$ with respect to seawater. While geochemical analysis of coral skeletons suggests that DIC is concentrated at the site of calcification [12], [DIC] derived from microelectrode measurements of carbonate in the CF indicate that [DIC] is similar to that of the surrounding seawater [13]. Further research is required to definitively resolve this issue.

\section{(d) Correlation of carbonate chemistry parameters with $\mathrm{pH}_{\mathrm{CF}}$}

The role of seawater carbonate chemistry in controlling coral calcification has been described previously [35-37] in terms of the ratio of seawater concentrations $[\mathrm{DIC}]_{\mathrm{SW}}:\left[\mathrm{H}^{+}\right]_{\mathrm{SW}}$. The authors of these previous pieces of work proposed that calcification is influenced by the $[\mathrm{DIC}]_{\mathrm{SW}}:\left[\mathrm{H}^{+}\right]_{\mathrm{SW}}$ ratio, as rates of calcification are limited by the supply of DIC and the accumulation of $\mathrm{H}^{+}$(i.e. a product of calcification) [36-38]. Reanalysis of data from several previous ocean acidification experiments supports the proposed relationship between $[\mathrm{DIC}]_{\mathrm{sw}} /\left[\mathrm{H}^{+}\right]_{\mathrm{sW}}$ and calcification rates [36-38].

To investigate whether there also was a relationship between $[\mathrm{DIC}]_{\mathrm{SW}} /\left[\mathrm{H}^{+}\right]_{\mathrm{SW}}$ ratio and $\mathrm{pH}_{\mathrm{CF}}$, we combined the data of this study with a previous confocal investigation on $\mathrm{pH}_{\mathrm{CF}}$ in S. pistillata [9]. Seawater treatments in this previous study involved $\mathrm{CO}_{2}$-driven decreases in seawater $\mathrm{pH}$ with relatively small increases in seawater [DIC] and no change in $\left[\mathrm{A}_{\mathrm{T}}\right]$ (as occurring with ocean acidification). First, net calcification was plotted (as values relative to controls) against $[\mathrm{DIC}]_{\mathrm{SW}} /\left[\mathrm{H}^{+}\right]_{\mathrm{SW}}$ (electronic supplementary material, figure S1) to reveal a linear relationship similar to those described previously [36-38]. $\mathrm{pH}_{\mathrm{CF}}$ (expressed as $\mathrm{CF}$ proton concentrations $\left.\left(\left[\mathrm{H}^{+}\right]_{\mathrm{CF}}\right)\right)$ was then plotted against various carbonate chemistry parameters and the $[\mathrm{DIC}]_{\mathrm{sw}} /$ $\left[\mathrm{H}^{+}\right]_{S W}$ and $\left[\mathrm{A}_{\mathrm{T}}\right]_{\mathrm{SW}} /\left[\mathrm{H}^{+}\right]_{S W}$ ratios (figure 6). These plots reveal that the compiled $\left[\mathrm{H}^{+}\right]_{\mathrm{CF}}$ of both studies exhibits a strong linear correlation with the $[\mathrm{DIC}]_{\mathrm{SW}} /\left[\mathrm{H}^{+}\right]_{\mathrm{SW}}$ ratio, the $\left[\mathrm{A}_{\mathrm{T}}\right] /\left[\mathrm{H}^{+}\right]_{\mathrm{SW}}$ ratio and $\left[\mathrm{CO}_{3}^{2-}\right]_{\mathrm{SW}}\left(R^{2}=0.75, p=0.006\right.$; $R^{2}=0.68, p=0.012$ and $R^{2}=0.71, p=0.010$, respectively). By contrast, compiled $\left[\mathrm{H}^{+}\right]_{\mathrm{CF}}$ values do not correlate with $\left[\mathrm{H}^{+}\right]_{\mathrm{SW}},[\mathrm{DIC}]_{\mathrm{SW}}$ or $\left[\mathrm{HCO}_{3}^{-}\right]_{\mathrm{SW}}(p>0.20)$.

These compiled data suggest that neither $\left[\mathrm{H}^{+}\right]_{\text {sw }}$ (i.e. seawater $\mathrm{pH}),[\mathrm{DIC}]_{\mathrm{SW}}$ nor $\left[\mathrm{HCO}_{3}^{-}\right]_{\mathrm{SW}}$ are controlling parameters of $\mathrm{pH}_{\mathrm{CF}}$. Instead the mechanism of $\mathrm{pH}_{\mathrm{CF}}$ depends on either the $[\mathrm{DIC}]_{\mathrm{SW}} /\left[\mathrm{H}^{+}\right]_{\mathrm{SW}}$ ratio, the $\left[\mathrm{A}_{\mathrm{T}}\right] /\left[\mathrm{H}^{+}\right]_{\mathrm{SW}}$ ratio or $\left[\mathrm{CO}_{3}^{2-}\right]_{\mathrm{SW}}$. Distinguishing between the $[\mathrm{DIC}]_{\mathrm{SW}} /\left[\mathrm{H}^{+}\right]_{\mathrm{SW}}$ ratio, the $\left[\mathrm{A}_{\mathrm{T}}\right] /\left[\mathrm{H}^{+}\right]_{\mathrm{SW}}$ ratio or $\left[\mathrm{CO}_{3}^{2-}\right]_{\mathrm{SW}}$ is not possible in the current experimental scenario. Deciphering the parameters modulating $\mathrm{pH}_{\mathrm{CF}}$ will rely on improving our current understanding of ion transport mechanisms in corals, particularly in terms of the exchange of $\mathrm{H}^{+}, \mathrm{HCO}_{3}^{-}$and $\mathrm{CO}_{3}^{2-}$ between the $\mathrm{CF}$ and the surrounding seawater.
Beyond gaining insights into biomineralization mechanisms in scleractinians, the correlations of $\left[\mathrm{H}^{+}\right]_{\mathrm{CF}}$ with carbonate chemistry parameters are of relevance to research into geochemical proxies, which have the goal of using isotopic signatures in coral skeletons as indicators of previous environmental conditions. For example, boron isotope systematics are used widely to determine $\mathrm{pH}_{\mathrm{CF}}[29,39]$, which used to be assumed to reflect seawater $\mathrm{pH}$ with an offset owing to the effects of $\mathrm{pH}_{\mathrm{CF}}$ regulation by the coral (sometimes referred to as a 'vital effect') $[40,41]$. However, the observed dependence of $\mathrm{pH}_{\mathrm{CF}}$ upregulation on [DIC] $]_{\mathrm{SW}}$ and the lack of correlation with seawater $\left[\mathrm{H}^{+}\right]$and $\left[\mathrm{H}^{+}\right]_{\mathrm{CF}}$ (figure 6) in this study serve to illustrate that a robust calibration of the vital effect cannot be uniquely conducted using an assumed offset of $\mathrm{pH}_{\mathrm{CF}}$ from seawater $\mathrm{pH}$.

\section{Conclusion}

This study determined that $\mathrm{pH}_{\mathrm{CF}}$ is influenced by shifts in seawater chemistry associated with changes in seawater [DIC] and $\left[\mathrm{A}_{\mathrm{T}}\right]$ at constant seawater $\mathrm{pH}$. This complements previous studies that have shown that similar carbonate chemistry treatments also modulate coral calcification rates [25]. In the light, availability of seawater [DIC] may affect photosynthetic rates, which is likely to influence $\mathrm{pH}_{\mathrm{CF}}$ and CF $\Omega$, and therefore calcification rates. In darkness, the observed increases in respiration rates may have contributed to lower $\mathrm{pH}_{\mathrm{CF}}$ in the lower seawater [DIC] and $\left[\mathrm{A}_{\mathrm{T}}\right]$ treatments. Our calicoblastic cell $\mathrm{pH}_{\mathrm{i}}$ data suggest that despite constant seawater $\mathrm{pH}$, changes in seawater carbonate chemistry may disturb calicoblastic cell $\mathrm{pH}_{\mathrm{i}}$ regulation, which may impair the ability of this cell layer to regulate $\mathrm{pH}_{\mathrm{CF}}$. Future cellular investigations into ion transport in corals and a better understanding of calicoblastic cell physiology are needed to explore this possibility further. Most notably, we demonstrate that $\mathrm{pH}_{\mathrm{CF}}$ expressed as $\left[\mathrm{H}^{+}\right]_{\mathrm{CF}}$ shows a strong linear correlation with seawater $\left[\mathrm{CO}_{3}^{2-}\right]_{S W}$, the $[\mathrm{DIC}]_{\mathrm{SW}} /\left[\mathrm{H}^{+}\right]_{\mathrm{SW}}$ ratio and the $\left[\mathrm{A}_{\mathrm{T}}\right] /\left[\mathrm{H}^{+}\right]_{\mathrm{SW}}$ ratio.

Overall, the observed effects of manipulated seawater carbonate chemistry on $\mathrm{pH}_{\mathrm{CF}}$ regulation in S. pistillata highlight that there is still much to learn about the physiological mechanisms controlling CF chemistry in scleractinians. Characterizing these mechanisms in scleractinians (as well as other calcifiers) is important to diverse lines of research including palaeoenvironmental reconstructions and predicting the response of calcifying organisms to the impending oceanic changes.

Data accessibility. See [31].

Authors' contributions. S.C., E.T., P.J.E., R.C.C., S.T. and A.V. conceived and designed research. S.C., E.T., N.R.E., C.F.-P. and A.V. performed the laboratory experiments. S.C., E.T., S.T., P.J.E., R.C.C., C.F.-P., D.A. and A.V. analysed data. All co-authors contributed to the manuscript and participated in scientific discussions of the findings.

Competing interests. We have no competing interests.

Funding. This study was supported by the National Science Foundation (OCE 10-41270 and 14-15268), the Government of the Principality of Monaco, and California State University, Northridge, Marine Biology (CSUN). This is contribution 250 of the CSUN, Marine Biology Programme. S.C. was supported by ARC (Discovery Early Career Researcher Award; DE160100668) during the writing of the manuscript. 
1. Weis VM, Allemand D. 2009 What determines coral health? Science 324, 1153-1155. (doi:10.1126/ science.1172540)

2. Venn A, Tambutté E, Holcomb M, Allemand D, Tambutté S. 2011 Live tissue imaging shows reef corals elevate $\mathrm{pH}$ under their calcifying tissue relative to seawater. PLOS ONE 6, e20013. (doi:10. 1371/journal.pone.0020013)

3. Ries JB. 2011 A physicochemical framework for interpreting the biological calcification response to $\mathrm{CO}_{2}$-induced ocean acidification. Geochim. Cosm. Acta 75, 4053-4064. (doi:10.1016/j.gca.2011. 04.025)

4. Zoccola D et al. 2015 Bicarbonate transporters in corals point towards a key step in the evolution of cnidarian calcification. Sci. Rep. 5, 09983. (doi:10. 1038/srep09983)

5. Gagnon AC, Adkins JF, Erez J. 2012 Seawater transport during coral biomineralization. Earth Planet. Sci. Lett. 329-330, 150-161. (doi:10. 1016/j.epsl.2012.03.005)

6. Tambutté $S$, Holcomb $M$, Ferrier-Pagès $C$, Reynaud S, Tambutté É, Zoccola D, Allemand D. 2011 Coral biomineralization: from the gene to the environment. J. Exp. Mar. Biol. Ecol. 408, 58-78. (doi:10.1016/j.jembe.2011.07.026)

7. Ganot $P$, Zoccola D, Tambutté E, Voolstra CR, Aranda M, Allemand D, Tambutté S. 2015 Structural molecular components of septate junctions in cnidarians point to the origin of epithelial junctions in eukaryotes. Mol. Biol. Evol. 32, 44-62. (doi:10. 1093/molbev/msu265)

8. Zoccola D, Tambutté E, Kulhanek E, Puverel S, Scimeca JC, Allemand D, Tambutté S. 2004 Molecular cloning and localization of a PMCA P-type calcium ATPase from the coral Stylophora pistillata. Biochim. Biophys. Acta (BBA) - Biomembranes 1663 , 117-126. (doi:10.1016/j.bbamem.2004.02.010)

9. Venn A, Tambutté E, Holcomb M, Laurent J, Allemand D, Tambutté S. 2015 Impact of seawater acidification on $\mathrm{pH}$ at the tissue-skeleton interface and calcification in reef corals. Proc. Natl Acad. Sci. USA 110, 1634-1639. (doi:10.1073/pnas.1216153110)

10. Al-Horani FA, Al-Moghrabi SM, De Beer D. 2003 The mechanism of calcification and its relation to photosynthesis and respiration in the scleractinian coral Galaxea fascicularis. Mar. Biol. 142, 419-426. (doi:10.1007/500227-002-0981-8)

11. McCulloch M, Falter J, Trotter J, Montagna P. 2012 Coral resilience to ocean acidification and global warming through $\mathrm{pH}$ up-regulation. Nat. Clim. Change 2, 623-627. (doi:10.1038/nclimate1473)

12. Allison N, Cohen I, Finch AA, Erez J, Tudhope AW. 2014 Corals concentrate dissolved inorganic carbon to facilitate calcification. Nat. Commun. 5, 5741. (doi:10.1038/ncomms6741)

13. Cai W-J et al. 2016 Microelectrode characterization of coral daytime interior pH and carbonate chemistry. Nat. Commun. 7, 11144. (doi:10.1038/ncomms11144)
14. Furla P, Galgani I, Durand I, Allemand D. 2000 Sources and mechanisms of inorganic carbon transport for coral calcification and photosynthesis. J. Exp. Biol. 203, 3445-3457.

15. Erez J. 1978 Vital effect on stable-isotope composition seen in foraminifera and coral skeletons. Nature 273, 199-202. (doi:10.1038/ 273199a0)

16. Pearse VB. 1970 Incorporation of metabolic $\mathrm{CO}_{2}$ into coral skeleton. Nature 228, 383. (doi:10.1038/ 228383a0)

17. Gaillardet J, Allègre U. 1995 Boron isotopic compositions of corals: seawater or diagenesis record? Earth Planet. Sci. Lett. 136, 665-676. (doi:10.1016/0012-821X(95)00180-K)

18. Pelejero C, Calvo E, McCulloch MT, Marshall JF, Gagan MK, Lough JM, Opdyke BN. 2005 Preindustrial to modern interdecadal variability in coral reef pH. Science 309, 2204-2207. (doi:10. 1126/science.1113692)

19. Hönisch B et al. 2012 The geological record of ocean acidification. Science 335, 1058-1063. (doi:10. 1126/science.1208277)

20. Muscatine L, Tambutté E, Allemand D. 1997 Morphology of coral desmocytes, cells that anchor the calicoblastic epithelium to the skeleton. Coral Reefs 16, 205-213. (doi:10.1007/s003380050075)

21. Jury CP, Whitehead RF, Szmant AM. 2010 Effects of variations in carbonate chemistry on the calcification rates of Madracis auretenra (= Madracis mirabilis sensu Wells, 1973): bicarbonate concentrations best predict calcification rates. Glob. Change Biol. 16, 1632-1644. (doi:10.1111/j.1365-2486.2009.02057. x)

22. Comeau S, Carpenter RC, Edmunds PJ. 2013 Coral reef calcifiers buffer their response to ocean acidification using both bicarbonate and carbonate. Proc. R. Soc. B 280, 20122374. (doi:10.1098/rspb. 2012.2374)

23. Marubini $F$, Ferrier-Pagès $C$, Furla $P$, Allemand $D$. 2008 Coral calcification responds to seawater acidification: a working hypothesis towards a physiological mechanism. Coral Reefs 27, 491-499. (doi:10.1007/s00338-008-0375-6)

24. de Putron SJ, McCorkle DC, Cohen AL, Dillon AB. 2010 The impact of seawater saturation state and bicarbonate ion concentration on calcification by new recruits of two Atlantic corals. Coral Reefs 30, 321-328. (doi:10.1007/s00338-010-0697-z)

25. Schneider K, Erez J. 2006 The effect of carbonate chemistry on calcification and photosynthesis in the hermatypic coral Acropora eurystoma. Limnol. Oceanogr. 51, 1284-1293. (doi:10.4319//0.2006.51. 3.1284)

26. Goiran C, Al-Moghrabi S, Allemand D, Jaubert J. 1996 Inorganic carbon uptake for photosynthesis by the symbiotic coral/dinoflagellate association I. Photosynthetic performances of symbionts and dependence on sea water bicarbonate. J. Exp. Mar.
Biol. Ecol. 199, 207-225. (doi:10.1016/00220981(95)00201-4)

27. Chisholm JRM, Gattuso J-P. 1991 Validation of the alkalinity anomaly technique for investigating calcification and photosynthesis in coral reef communities. Limnol. Oceanogr. 36, 1232-1239. (doi:10.4319/l0.1991.36.6.1232)

28. Veal C, Carmi M, Fine M, Hoegh-Guldberg 0. 2010 Increasing the accuracy of surface area estimation using single wax dipping of coral fragments. Coral Reefs 29, 893-897. (doi:10.1007/s00338-010-06479)

29. Holcomb M, Venn AA, Tambutté E, Tambutté $S$, Allemand D, Trotter J, McCulloch M. 2014 Coral calcifying fluid $\mathrm{pH}$ dictates response to ocean acidification. Sci. Rep. 4, 5207. (doi:10.1038/ srep05207)

30. Hoogenboom M, Béraud E, Ferrier-Pagès C. 2010 Relationship between symbiont density and photosynthetic carbon acquisition in the temperate coral Cladocora caespitosa. Coral Reefs 29, 21-29. (doi:10.1007/s00338-009-0558-9)

31. Comeau S, Tambutté E, Carpenter RC, Edmunds PJ, Evensen NR, Allemand D, Ferrier-Pagès C, Tambutté S, Venn A. 2016 Coral calcifying fluid $\mathrm{pH}$ is modulated by seawater carbonate chemistry not solely seawater $\mathrm{pH}$. Dataset no. 868353. (doi:pangaea.de/10.1594/ PANGAEA.868353)

32. Wolf-Gladrow DA, Zeebe RE, Klaas C, Körtzinger A, Dickson AG. 2007 Total alkalinity: the explicit conservative expression and its application to biogeochemical processes. Mar. Chem. 106, 287-300. (doi:10.1016/j.marchem.2007.01.006)

33. Busa WB, Nuccitelli R. 1984 Metabolic regulation via intracellular pH. Am. J. Physiol. 246, R409-R438.

34. Muscatine L, Goiran C, Land L, Jaubert J, Cuif J-P, Allemand D. 2005 Stable isotopes $\left(\delta^{13} \mathrm{C}\right.$ and $\left.\delta^{15} \mathrm{~N}\right)$ of organic matrix from coral skeleton. Proc. Natl Acad. Sci. USA 102, 1525-1530. (doi:10.1073/pnas. 0408921102)

35. Mass T, Drake JL, Haramaty L, Dongun Kim J, Zelzion E, Bhattacharya D, Falkowski PG. 2013 Cloning and characterization of four novel coral acid-rich proteins that precipitate carbonates in vitro. Curr. Biol. 23, 1126-1131. (doi:10.1016/j.cub. 2013.05.007)

36. Jokiel PL. 2011 The reef coral two compartment proton flux model: a new approach relating tissuelevel physiological processes to gross corallum morphology. J. Exp. Mar. Biol. Ecol. 409, 1-12. (doi:10.1016/j.jembe.2011.10.008)

37. Jokiel PL. 2013 Coral reef calcification: carbonate, bicarbonate and proton flux under conditions of increasing ocean acidification. Proc. R. Soc. B 280, 20130031. (doi:10.1098/rspb.2013.0031)

38. Bach LT. 2015 Reconsidering the role of carbonate ion concentration in calcification by marine 
organisms. Biogeosciences 12, 4939-4951. (doi:10. 5194/bg-12-4939-2015)

39. Georgiou L, Falter J, Trotter J, Kline DI, Holcomb M, Dove SG, Hoegh-Guldberg 0, McCulloch M. 2015 pH homeostasis during coral calcification in a free ocean $\mathrm{CO}_{2}$ enrichment (FOCE) experiment, Heron Island reef flat, Great Barrier Reef. Proc. Natl Acad. Sci. USA
112, 13 219-13 224. (doi:10.1073/pnas. 1505586112)

40. Trotter J et al. 2011 Quantifying the pH 'vital effect' in the temperate zooxanthellate coral Cladocora caespitosa: validation of the boron seawater $\mathrm{pH}$ proxy. Earth Planet. Sci. Lett. 303, 163-173. (doi:10.1016/j.epsl.2011.01.030)
41. Hönisch B, Hemmings NG, Grottoli AG, Amat A, Hanson GN, Bijma J. 2004 Assessing scleractinian corals as recorders for paleo-pH: empirical calibration and vital effects. Geochim. Cosmochim. Acta 68, 3675-3685. (idoi:10.1016/ j.gca.2004.03.002) 